medRxiv preprint doi: https://doi.org/10.1101/2020.06.19.20135467; this version posted June 22, 2020. The copyright holder for this preprint (which was not certified by peer review) is the author/funder, who has granted medRxiv a license to display the preprint in perpetuity.

All rights reserved. No reuse allowed without permission.

\title{
Nationwide incidence of sarcomas and connective tissue tumors of intermediate malignancy over four years using an expert pathology review network.
}

Prof. Gonzague de Pinieux MD, PhD ${ }^{* 1}$, Marie Karanian-Philippe $\mathrm{MD}{ }^{* 2}$, Francois Le Loarer MD, $\mathrm{PhD}^{*}$, Sophie Le Guellec $\mathrm{MD}^{4}$, Sylvie Chabaud $\mathrm{PhD}^{2}$, Philippe Terrier $\mathrm{MD}{ }^{5}$, Corinne Bouvier $\mathrm{MD}, \mathrm{PhD}^{6}$, Maxime Battistella $\mathrm{MD}, \mathrm{PhD}^{7}$, Agnès Neuville $\mathrm{MD}, \mathrm{PhD}^{3}$, Yves-Marie Robin $\mathrm{MD}^{8}$, JeanFrancois Emile MD, $\mathrm{PhD}^{9}$, Anne Moreau MD ${ }^{10}$, Frederique Larousserie MD, PhD ${ }^{11}$, Agnes Leroux $M D^{12}$, Nathalie Stock MD ${ }^{13}$, Marick Lae MD ${ }^{14}$, Francoise Collin $M D^{15}$, Nicolas Weinbreck $M D^{16}$, Sebastien Aubert $\mathrm{MD}^{8}$, Florence Mishellany $\mathrm{MD}^{17}$, Céline Charon-Barra $\mathrm{MD}^{15}$, Sabrina Croce MD, $\mathrm{PhD}^{3}$, Laurent Doucet MD ${ }^{18}$, Isabelle Quintin-Rouet $\mathrm{MD}^{18}$, Marie-Christine Chateau MD ${ }^{19}$, Celine Bazille $\mathrm{MD}^{20}$, Isabelle Valo $\mathrm{MD}^{21}$, Bruno Chetaille $\mathrm{MD}^{16}$, Nicolas Ortonne $\mathrm{MD}^{22}$, Anne Gomez-Brouchet $\mathrm{MD}, \mathrm{PhD}^{4}$, Philippe Rochaix $\mathrm{MD}^{4}$, Anne De Muret $\mathrm{MD}^{1}$, Jean-Pierre Ghnassia MD, $\mathrm{PhD}^{23}$, Lenaig Mescam-Mancini MD ${ }^{25}$, Nicolas Macagno MD ${ }^{6}$, Isabelle Birtwisle-Peyrottes MD ${ }^{26}$, Christophe Delfour $M D^{19}$, Emilie Angot $M D^{13}$, Isabelle Pommepuy $M D^{2}$, Dominique Ranchere-Vince $M D^{2}$, Claire CheminAiriau $\mathrm{MSc}^{2}$, Myriam Jean-Denis $\mathrm{MSc}^{2}$, Yohan Fayet $\mathrm{PhD}^{2}$, Jean-Baptiste Courrèges $\mathrm{MSc}^{3}$, Nouria Mesli MSc ${ }^{3}$, Juliane Berchoud $\mathrm{MSc}^{10}$, Maud Toulmonde MD, $\mathrm{PhD}^{3}$, Prof. Antoine Italiano MD, $\mathrm{PhD}^{3}$, Axel Le Cesne $\mathrm{MD}^{2}$, Nicolas Penel MD, PhD ${ }^{8}$, Francoise Ducimetiere $\mathrm{PhD}^{2}$, Prof. Francois Gouin MD, $\mathrm{PhD}^{2^{* *}}$, Prof. Jean-Michel Coindre MD, $\mathrm{PhD}^{3 * *}$, Prof. Jean-Yves Blay MD, $\mathrm{PhD}^{2^{* *}}$.

on behalf of the NETSARC/REPPS/RESOS and French Sarcoma Group-Groupe d'Etude des Tumeurs Osseuses (GSF-GETO) networks (Supplementary data, document 1).

*: the first 3 authors (alphabetical order) contributed equally to this work.

** : the last 3 authors contributed equally to this work

\section{Affiliation list}

1. CHU de Tours, Tours, France

2. Centre Léon Bérard \& Université Claude Bernard, Lyon \& Unicancer, Paris, France

3. Institut Bergonié, Bordeaux, France

4. Institut Claudius Regaud et Institut Universitaire du Cancer de Toulouse - Oncopôle, Toulouse,

France

5. Gustave Roussy, Villejuif, France

6. La Timone University Hospital, Marseille, France

7. Pathology Department, Saint-Louis Hospital, AP-HP, Université de Paris, INSERM U976, Paris,

France

NOTE: This preprint reports new research that has not been certified by peer review and should not be used to guide clinical practice. 
medRxiv preprint doi: https://doi.org/10.1101/2020.06.19.20135467; this version posted June 22, 2020. The copyright holder for this preprint

(which was not certified by peer review) is the author/funder, who has granted medRxiv a license to display the preprint in perpetuity.

All rights reserved. No reuse allowed without permission.

8. Pôle de Biologie-Pathologie-Génétique Centre Oscar Lambret, \& Institut de Pathologie

CHU Lille, Avenue Oscar Lambret Lille, Lille, France

9. Hopital Ambroise Paré, Boulogne, France

10. Department of Pathology, Department of Orthopedy CHU Nantes, France

11. Hôpital Cochin-Saint-Vincent de Paul, Paris, France

12. Institut de Cancérologie de Lorraine - Alexis Vautrin, Vandoeuvre-lès-Nancy, France

13. Eugene Marquis Comprehensive Cancer Center \& CHU Rennes, Rennes France

14. Institut Curie, Paris, France

15. Centre Georges François Leclerc, Dijon, France

16. Medipath, Frejus, France

17. Centre Jean Perrin, Clermont-Ferrand, France

18. CHRU Brest, Brest, France

19. Institut de Cancérologie de Montpellier \& CHU Montpellier, France

20. Centre Francois Baclesse, Caen, France

21. Department of Pathology, Institut de Cancerologie de l'Ouest, Angers, France

23. APHP Hopital Henri Mondor, Creteil, France

24. Centre Paul Strauss, Strasbourg France

25. Institut Paoli Calmettes, Marseille, France

26. Centre Antoine-Lacassagne, Nice, France

27. CHU Limoges, Limoges, France

Correspondence to Prof J.-Y Blay, Department of Medical Oncology, Centre Léon Bérard, 28 rue Laënnec, 69373 Lyon Cedex 08, \& Université Claude Bernard Lyon I France. Tel: +33 (0)4 787851 26, jean-yves.blay@lyon.unicancer.fr

\section{Funding}

NetSARC (INCA \& DGOS) and RREPS (INCA \& DGOS), RESOS (INCA \& DGOS) and LYRICAN (INCA-DGOSINSERM 12563), Institut Convergence PLASCAN (17-CONV-0002), Association DAM's, Ensemble contre Le GIST, Eurosarc (FP7-278742), la Fondation ARC, Infosarcome, InterSARC (INCA), LabEx DEvweCAN (ANR-10-LABX-0061), Ligue de L'Ain contre le Cancer, La Ligue contre le Cancer, EURACAN (EC 739521) funded this study.

Keywords: Sarcoma, rare cancers, rare diseases, clinical practice guidelines, surgery, relapse, survival, reference centers.

Conflict of Interest: the authors report no conflict of interest related to this work. 
medRxiv preprint doi: https://doi.org/10.1101/2020.06.19.20135467; this version posted June 22, 2020. The copyright holder for this preprint

(which was not certified by peer review) is the author/funder, who has granted medRxiv a license to display the preprint in perpetuity.

All rights reserved. No reuse allowed without permission.

\section{Abstract ( $\mathrm{N}=\mathbf{2 2 8}$ words)}

\section{Background:}

Since 2010, NETSARC and RREPS collected and reviewed prospectively all cases of sarcomas and tumors of intermediate malignancy (TIM) nationwide.

\section{Methods:}

The nationwide incidence of sarcoma or TIM (2013-2016), confirmed by expert pathologists using WHO classification are presented. Yearly variations and correlation with published clinical trials was analyzed.

\section{Results:}

139 histological subtypes are reported among the 25172 patients with sarcomas ( $n=18710,64 \%$ ) or TIM ( $n=6460,36 \%$ ), respectively $n=5838, n=6153, n=6654$, and $n=6527$ yearly from 2013 to 2016 .

Over these 4 years, the yearly incidence of sarcomas and TIM was therefore 79.7, 24.9 and $95.1 / 10^{6} /$ year, above that previously reported. GIST, liposarcoma, leiomyosarcomas, undifferentiated sarcomas represented $13 \%, 13 \%, 11 \%$ and $11 \%$ of tumors. Only GIST, as a single entity had a yearly incidence above 10/million/year. There were respectively 30,63 and 66 different histological subtypes of sarcomas or TIM with an incidence ranging from 10 to $1 / 10^{6}, 1-0.1 / 10^{6}$, or $<0.1 / 10^{6}$ /year respectively. The 2 later "incidence groups" included $21 \%$ of the patients. The incidence of 8 histotypes varied significantly over this 4 years. Patients with tumors with an incidence above $1 / 10^{6}$ per year have significantly higher numbers of dedicated published phase III and phase II clinical trials $\left(p<10^{-6}\right)$.

\section{Conclusions:}

This nationwide registry of sarcoma patients with histology reviewed by sarcoma experts shows that the incidence of sarcoma and TIM is higher than reported, and that tumors with an incidence $<10^{6} /$ year have a much lower access to clinical trials. 
medRxiv preprint doi: https://doi.org/10.1101/2020.06.19.20135467; this version posted June 22, 2020. The copyright holder for this preprint

(which was not certified by peer review) is the author/funder, who has granted medRxiv a license to display the preprint in perpetuity.

All rights reserved. No reuse allowed without permission.

\section{Introduction}

Sarcomas is an heterogeneous group of rare connective tissue cancers, with variable clinical presentations, and a reported incidence thought to be close to $2 / 10^{5}$ /year 15 years ago, which has more recently been reported to range from 3 to $7 / 10^{5} /$ year $(1-16)$.

The reported incidence of sarcoma varies considerably across countries and according to the date of analysis (2-16). The overall incidence of sarcoma is therefore not precisely known, and even less so that of individual histological subtypes, which are not unfrequently misdiagnosed. Indeed, because of their rarity, sarcoma are initially misclassified in up to $30 \%$ of cases $(1,5,6,11,17)$. As a consequence patients with sarcomas may not treated according to clinical practice guidelines (1-21). In all clinical practice guidelines, it is recommended that the diagnosis of sarcoma should be confirmed by an expert pathologist. In general, management of sarcoma patients should be performed by a dedicated multidisciplinary team, including expert pathologists and surgeons, treating a large number of patients (5-7). It was recently reported that central pathology review of sarcoma cases is cost effective, reducing both morbidity, mortality and cost of management $(22,23)$.

Since 2010, the French National Cancer Institute (INCa) funded pathology and clinical networks for sarcoma called RREPS and NETSARC, subsequently joined by RESOS focused on bone sarcomas, to improve the quality of management of sarcoma patients. Initially, the network of 23 expert reference centers for pathology (RRePS) was in charge of the mandatory histological review for each suspected case of sarcoma nationwide. These networks have merged since 2019 in a single NETSARC+ network. The common database (netsarc.org) gathering all cases of sarcoma presented to MDTB was created and implemented, collected data on the diagnostic, therapeutic management, and the clinical outcome in terms of relapse and survival. From Jan $1^{\text {st }} 2010$, this database prospectively included over 59000 patients with sarcoma or tumor of intermediate malignancy. Since 2013, the overall accrual in the database reached a plateau, suggesting that the closest to exhaustive collection of cases in this country was obtained.

The incidence of sarcoma and TIM has seldom been reported in exhaustive nationwide series with organized reference center pathology review. We report here on the incidence of the different histological subtypes of sarcomas and TIM reported in the NETSARC+ database from 2013 to 2016. 
medRxiv preprint doi: https://doi.org/10.1101/2020.06.19.20135467; this version posted June 22, 2020. The copyright holder for this preprint (which was not certified by peer review) is the author/funder, who has granted medRxiv a license to display the preprint in perpetuity.

All rights reserved. No reuse allowed without permission.

\section{Patient, material and methods}

\section{The NETSARC+ network and the referral of the pathology sample to the network of experts.}

The RREPS (pathology, NETSARC (clinical management), and RESOS (bone sarcoma) networks which gathered experts from the same centers were merged into the NETSARC+ network in 2019. The organization of these networks has been reported previously $(24,25)$ : each RREPS and NETSARC center organizes a multidisciplinary tumor board (MDTB) gathering sarcoma specialized pathologist(s), radiologist(s), surgeon(s), radiation oncologist(s), medical oncologist(s), and often molecular biologist(s), orthopedist(s), pediatrician(s).

Since 2010, it is mandatory for the primary pathologist to refer all suspected cases of sarcomas or TIM to one of the reference centers. In addition, if this has not been done previously, pathology review is will be requested for any clinical case referred to one of the 26 multidisciplinary tumor board of NETSARC without initial prior central pathology review, thus ensuring a double check. These two modes of entry improve the rate of review of the sarcoma/TIM samples nationwide. All sarcoma/TIM or suspected sarcoma/TIM patient cases presented to the MDTB of all 26 centers were recorded in the electronic online database, by a dedicated team of Clinical research assistant (CRAs), supervised by the Coordinating centers (Centre Leon Bérard, Gustave Roussy, Institut Bergonié, CHU Tours, CHU Nantes). Patient files may be presented before any diagnostic procedure, before initial biopsy, before primary surgery, after primary surgery, at relapse, and/or in case of a possible inclusion in a clinical trial as previously described $(24,25)$. Patients and treatment data were prospectively included and regularly updated by the dedicated study coordinators.

\section{The RREPS/NETSARC Database}

The RREPS/NETSARC database may therefore enable to describe as exhaustively as possible the incident and prevalent population of sarcoma patients in France. Of note, the database includes a limited set of data, on purpose, describing patients and tumor characteristics, surgery, relapse and survival $(24,25)$, centers performing the first resection, as well as potential secondary surgery types and sites, the final quality of resection, etc...

Of note, about $24 \%$ of patients in the database discussed in a NETSARC MDTB had a diagnosis which was not that of a sarcoma/TIM (e.G. lipoma, carcinoma, lymphoma...). Again, it is important to note that in NETSARC, patients with suspected sarcoma/TIM can enter the process of MDTB either through the pathology network, or directly by the physician, leading both to a final MDTB review after central pathology confirmation.

All data presented here were extracted from the NETSARC.org database accessible online for a period of 4 years between 2013 and 2016. These 4 years were selected since: 1) the yearly incidence of sarcoma and TIM started to plateau since 2013, and 2) data monitoring and implementation is still ongoing for year 2017 and later.

\section{Presentation of the data}

The WHO classification is used to describe the histological subtypes in the database (1). The number of patients for each individual histological subtype of sarcoma or TIM per year, from 2013 to 2016, is therefore presented in these tables. To facilitate the comparison with other databases using previous classifications, the incidence for groups of tumors are also presented in the Tables, when they are clinically relevant (e.g. uterine sarcoma), or used as entities for clinical trials (e.g. liposarcomas, leiomyosarcoma, solitary fibrous tumors, giant cell tumors of the bone...). To estimate the incidence of these tumors, we used the official number of French citizens in the years 2013 to 2016, which were respectively 65.56, 66.13, 66.42 and 66.60 millions inhabitants.

\section{Matching histotypes with published clinical trials}

Each individual histotype was screened to identify a dedicated clinical trial within the Pubmed database. The name of the entity (e.g. angiosarcoma, pleomorphic liposarcoma...) was used in the interrogation, together with a filter on clinical trial, adding " phase III ", " randomized phase II », or « phase II ». Pubmed was interrogated between Jan 15 and Jan 302020.

\section{Statistical analyses}


medRxiv preprint doi: https://doi.org/10.1101/2020.06.19.20135467; this version posted June 22, 2020. The copyright holder for this preprint

(which was not certified by peer review) is the author/funder, who has granted medRxiv a license to display the preprint in perpetuity.

All rights reserved. No reuse allowed without permission.

The number of patient per year with the different histotypes is presented in tables. To analyze the variation of incidence over the 4 years, an ANOVA procedure was used for the whole dataset. Histotypes with a significant variation in the period of observation are detailed. The comparison of the frequency of published clinical trials per histological subtypes or groups of subtypes was performed using the chi square or Fisher's exact test. All statistical tests were two-sided. All statistical analyses were performed using SPSS (v 23.0) (IBM, Paris France).

\section{Funding}

NetSARC (INCA \& DGOS) and RREPS (INCA \& DGOS), RESOS (INCA \& DGOS) and LYRICAN (INCA-DGOS-INSERM 12563), Institut Convergence PLASCAN (17-CONV-0002), Association DAM's, Ensemble contre Le GIST, Eurosarc (FP7-278742), la Fondation ARC, Infosarcome, InterSARC (INCA), LabEx DEvweCAN (ANR-10-LABX-0061), Ligue de L'Ain contre le Cancer, La Ligue contre le Cancer, EURACAN (EC 739521) funded the study. The funders had no role in the study design, data collection, data analysis, data interpretation, or writing of the report. 
medRxiv preprint doi: https://doi.org/10.1101/2020.06.19.20135467; this version posted June 22, 2020. The copyright holder for this preprint (which was not certified by peer review) is the author/funder, who has granted medRxiv a license to display the preprint in perpetuity.

All rights reserved. No reuse allowed without permission.

\section{Results}

\section{Incidence of sarcoma and TIM in NETSARC}

Table 1 to 3 present the incidence of the individual histological subtypes of soft tissue, visceral, bone sarcomas or connective tissue tumors included in the NETSARC+ databases from 2013 to 2016, the first 4 years for which it was considered close to exhaustive. From 2013 to 2016, a total of 25172 incident patients were included in the database (Table 1 and 2), with $n=5838, n=6153, n=6654$, and $n=6527$ new patients for each year.

The NETSARC database includes 156 individual tumors or groups of sarcoma/TIM, 31 groups of sarcomas/TIM (e.g. « liposarcoma ») and 125 distinct individual histological subtypes of sarcomas or TIM (Table 1-3). Twelve additional histological subtypes of bone sarcomas (leiomyosarcomas, synovial etc) were also distinguished in this work (Table 3). Finally, Table 3 also presents the incidence of sarcomas diagnosed in patients with reported genetic predispositions.

With an official number of the French population of $65.56,66.13,66.42$ and 66.60 millions inhabitants in these 4 years, the estimated incidence of sarcomas and tumors of intermediate malignancy from 2013 to 2016 was $89.05,93.04,100.18$, and 98.00 per million inhabitants respectively. Over these 4 years, the estimated yearly incidence of sarcomas and TIM was therefore $95,10 / 10^{6} /$ year.

There were 18710 (64\%) patients with sarcomas (incidence $70.87 / 10^{\%} /$ year) and $6460(36 \%$, $24.47 / 10^{6} /$ year) patients with TIM.

The observed overall incidence of sarcoma and TIMs is therefore above that previously reported (1-15).

\section{Over 100 -fold difference in incidence in different sarcoma histotypes}

Figure 1 presents the individual histotypes and relevant groups of histotypes (eg liposarcoma, leiomyosarcoma, unterine sarcomas) ordered by incidence. GIST, liposarcoma, leiomyosarcomas, undifferentiated sarcomas represented $13 \%, 13 \%, 11 \%$ and $11 \%$ of all sarcomas ( $47 \%$ all 4 together). Only gastrointestinal stromal tumors, if considered as single entities, exceeded a yearly incidence above $10 / 10^{6} /$ year (Figure 1). The other histological types of sarcomas with a yearly incidence above 10/106/year are histotypes groups 1) all liposarcomas, 2) all smooth muscle tumors, 3) all undifferentiated sarcomas, and 4) all fibroblastic or myofibroblastic tumors lumped together. This later group a group is not clinically homogenous and usually not considered as a specific entity in clinical trials or retrospective studies.

There were respectively 35, 63 and 66 different histological subtypes or groups (e.g. MPNST, or vascular sarcomas...) of sarcomas or TIM with an incidence ranging from 10 to $1 / 10^{6}$ /year, $1-0.1 / 10^{6}$ per year, or $<0.1 / 10^{6} /$ year respectively.

These 3 groups gathered respectively 18542 (74\%), $4766(19 \%)$ and $568(2 \%)$ of patients. The total number of patients in the different incidence groups exceeds the total number of patients of the series since some histological subtypes are listed as a group : for instance all liposarcoma as well as individual subtypes of liposarcomas (eg myxoid liposarcoma) are both listed.

A simple description of mean age, sex ratio, and site of the tumori s presented in table 4 . It also shows the large clinical heterogeneity of these tumors with a mean age ranging from 5 years (infantile fibrosarcoma) to 78 (atypical fibroxanthoma), and a sex ratio from 0 (for sexual organs) to 153 for adenosarcoma.

\section{Variable incidence of sarcoma histotypes over the 2013-2016 period}

We investigated then the variability of the yearly incidence of these different tumors in the database. The analysis of variance of the observed incidence indicated a significant interaction between time and histology $(p<0.001)$. Supplementary figure presents the eight histological subtypes whose yearly incidence was found to vary significantly between 2013 and 2016. Adenosarcoma, central chondrosarcoma, solitary fibrous tumour, endometrial stromal sarcoma - high-grade increaseover the4 years, while intimal sarcoma, Kaposi sarcoma, Liposarcoma - round cell, myoepithelioma apprear to decrease. Most have an incidence $<1 / 10^{6}$ year. While for Kaposi sarcoma, this maybe related to the evolving 
medRxiv preprint doi: https://doi.org/10.1101/2020.06.19.20135467; this version posted June 22, 2020. The copyright holder for this preprint

(which was not certified by peer review) is the author/funder, who has granted medRxiv a license to display the preprint in perpetuity. All rights reserved. No reuse allowed without permission.

epidemiology of an associated condition (HIV infection), the significance of these variations remain unclear and will deserve to be explored in other registries with a central review.

\section{Incidence of individual histotypes and published clinical trials}

Figure 1 presents graphically, and in ranking order (decreasing), the incidence of the different histotypes and groups of histotypes. These were matched with the presence of a published clinical trial on Pubmed focused specifically on this histological group (eg liposarcoma) or specific histotype (e.g. pleomorphic liposarcoma). Phase III studies, randomized phase II studies, and non randomized phase II studies are indicated in green, dark blue and light blue respectively. An histological subtype is considered covered by a trial only if the trial includes a specific arm (phase II) or a specific strata (phase III) in this given histotype.

As expected, phase III trials are available mostly in histotypes or groups of histotypes with an incidence $>1 / 10^{6}$ per year (Figure 1).

14 of $35(40 \%)$ histotypes with an incidence $>1 / 10^{6}$ had a dedicated phase III study vs 6 of $129(4.6 \%)$ histotypes for sarcomas with a incidence $<1 / 10^{6}\left(p<10^{-6}\right) .20100(79,7 \%)$ patients of the database had a specific histotype for which no phase III trial had been reported. 21 of $35(60 \%)$ histotypes with an incidence $>1 / 10^{6}$ had a dedicated randomized phase II study vs 10 of $129(7.7 \%)$ histotypes for sarcomas with a incidence $\left.<1 / 10^{6}\left(p<10^{-10}\right)\right) .13154$ (52.1\%) patients of the database had a specific histotype for which no randomized phase II trial had been reported.

Twenty-eight of $35(80 \%)$ histotypes with an incidence $>1 / 10^{6}$ had a dedicated phase III study vs 36 of $129(27.9 \%)$ histotypes for sarcomas with a incidence $<1 / 10^{6}\left(p<10^{-8}\right) .6516$ $(25.8 \%)$ patients of the database had a specific histotype for which no phase II trial had been reported. 
medRxiv preprint doi: https://doi.org/10.1101/2020.06.19.20135467; this version posted June 22, 2020. The copyright holder for this preprint (which was not certified by peer review) is the author/funder, who has granted medRxiv a license to display the preprint in perpetuity.

All rights reserved. No reuse allowed without permission.

\section{Discussion}

The objective of this work was to describe the incidence of individual histological subtypes of sarcomas and TIM according to the most recent WHO classification. These cases were collected from the single NETSARC+ database, gathering the previous RREPS, RESOS and NETSARC databases (netsarc.org).

This work supported by the French $\mathrm{NCl}$ allowed therefore to measure the incidence of sarcomas and TIM in a nationwide database, close to exhaustivity given the stringent criteria of central pathology review in place since 2010. Since 2013, the number of patients included in the database per year is relatively stable suggesting that this is close to exhaustivity. We stopped the description on year 2016, since years 2017 to 2019 are still being monitored by the NETSARC+ now.

The first important observation is that the incidence of these tumors is larger than previously reported in each of these 4 years (1-15). Recently published data from countries in 4 continents reported an overall incidence ranging from 3 to $7.7 / 10^{6} /$ year. The results of these studies are also heterogenous in terms of respective proportion of the groups of histotypes, ranging from 4 to $20 \%$ for undifferentiated sarcomas for instance. Taken together these observations suggest that mandatory central pathology review, results in a higher than reported incidence of almost all subtypes.

The present work also confirm that sarcoma histotype is a highly fragmented group of diseases, whose individual incidences may range from $10 / 10^{6}$ to less than $0.01 / 10^{6}$, ie a $>1000$-fold difference in incidence for tumors altogether considered as rare according to the international classification.

This is also a highly heterogenous group of tumors in terms of clinical presentations as shown by the diversity of sex ratio and mean age for diagnosis. Each of these entities should therefore benefit from a specific research programs to describe their natural history as well as the impact of current treatment on their disease course. This require a coordinated effort, worldwide, to achieve this goal given the rarity of certain histotypes. This is currently being conduction by intergroup studies, and international networks such as EURACAN. This work also confirms the important of national registries to investigate these rare subtypes.

An intriguing observation is that the incidence of these tumor may vary over time, and this was observed to be significant for 8 histotypes. While etiologic reasons may account fgor the reduction of Kaposi sarcoma in this time period, there is no obvious explanation for the seven other histotypes. Given the stability of the pathology team over this period this is not likely resulting from the pathology review. Epidemiological studies in other countries may be useful to confirm these variations, which may guide research on etiology of these most often rare sarcomas and TIM.

Another observation, expected by clinicians, is the link between the incidence and the availability of published prospective clinical research work to guide the management of individual subtypes. For decades the medical treatment of sarcomas used a one-size-fits-all approach for phase II to III clinical trials. Since 15 years, dedicated randomized phase II, III and phase II studies were implemented for specific histological subtypes, starting with GIST. This is more the exception of the rule though. The majority of histotypes described in this work, expecially those with an incidence under $1 / 10^{6} /$ year have not had a dedicated phase II, randomized phase II or phase III clinical trial to guide clinical practice guidelines. This represents the majority of these patients for phase III, and still about $25 \%$ of the patients for phase II. This calls for a revision of the criterias to define standard treatment for such rare tumors where phase III are not feasible. Health authorities and reimbursement bodies should adapt their decisions on approval and reimbursement on the feasible level of evidence which could be reached for tumors with and incidence $<1 / 10^{\mathrm{e}} 6$ per year in order not to discriminate against patients with rare cancers. It is important to remember that altogether patient with rare cancers represent $22 \%$ of all patient swith cnacers, and about $30 \%$ of the mortality due to cancer (26).

This study has many limitations. We can not exclude that patients may not reach our network despite the administrative incentive. This is true in particular for bone sarcoma and TIM (e.g. chondroblastomas, osteoblastoma, aneurysmatic bone cyst, etc..) which were collected more recently. The work must also adapt the the rapidly evolving classification of sarcomas, including now molecular subclassifications, which are not described here (for instance GIST, 
medRxiv preprint doi: https://doi.org/10.1101/2020.06.19.20135467; this version posted June 22, 2020. The copyright holder for this preprint

(which was not certified by peer review) is the author/funder, who has granted medRxiv a license to display the preprint in perpetuity.

All rights reserved. No reuse allowed without permission.

the novel NTRK sarcoma subgroup, BCOR, CIC-DUX4 sarcomas). To further explore the exhaustivity of the NETSARC+ bases, an ongoing project connects this base to the social security data base (SNDS) the single payer in France covering all citizens for all diseases (the Deepsarc project). This should enable a further refinement of these numbers.

Nevertheless, the observation that the incidence of sarcomas and TIM was higher than previously reported in this work during this time period provides a valuable information for this group of tumors.

In conclusion, this nationwide registry describes the incidence of sarcoma and TIM at a nationwide level over a 4 year period, with a central sarcoma pathologist expert review. It provides a benchmark for comparison with other registries worldwide and confirm the limitations of clinical research in sarcomas with an incidence $<10^{6}$ per year. The observation of variable incidence for specific histological suibtype is intringuing and should be compared with data from other countries. Geographical research on the distribution of these cases over the national territory are ongoing. 
medRxiv preprint doi: https://doi.org/10.1101/2020.06.19.20135467; this version posted June 22, 2020. The copyright holder for this preprint (which was not certified by peer review) is the author/funder, who has granted medRxiv a license to display the preprint in perpetuity.

All rights reserved. No reuse allowed without permission.

\section{References}

1. Fletcher CDM, JA Bridge, PCW Hogendoorn, Mertens F. Pathology and genetics of tumours of soft tissue and bone. World Health Organization. IARC Press: Lyon 2013.

2. Zahm SH, Fraumeni JF Jr. The epidemiology of soft tissue sarcoma. Semin Oncol. 1997; 24:504-14.

3. Clark MA, Fisher C, Judson I, Thomas JM. Soft-tissue sarcomas in adults. N Engl J Med. 2005 ; 353:701-11.

4. Alvegård T, Sundby Hall K, Bauer H, Rydholm A. The Scandinavian Sarcoma Group: 30 years' experience. Acta Orthop Suppl. $2009 ; 80: 1-104$.

5. Mastrangelo G, Fadda E, Cegolon L, et al. A European project on incidence, treatment, and outcome of sarcoma. BMC Public Health. 2010;10:188.

6. Ducimetière $F$, Lurkin $A$, Ranchère-Vince $D$, et al. Incidence of sarcoma histotypes and molecular subtypes in a prospective epidemiological study with central pathology review and molecular testing. PLoS One. 2011;6:e20294.

7. Ray-Coquard I, Montesco MC, Coindre JM, Dei Tos AP, Lurkin A, Ranchère-Vince $D$, Vecchiato A, Decouvelaere AV, Mathoulin-Pélissier S, Albert S, Cousin P, Cellier D, Toffolatti L, Rossi CR, Blay JY. Sarcoma: concordance between initial diagnosis and centralized expert review in a population-based study within three European regions. Ann Oncol. 2012;23:2442-2449.

8. C.A. Stiller, A. Trama, D. Serraino, S. et al, The RARECARE Working Group Descriptive epidemiology of sarcomas in Europe: Report from the RARECARE project. European Journal of Cancer 2013;49:684- 695.

9. Gatta G, Capocaccia R, Botta L, Mallone S, De Angelis R, Ardanaz E, Comber H, Dimitrova N, Leinonen MK, Siesling S, van der Zwan JM, Van Eycken L, Visser O, Žakelj MP, Anderson LA, Bella F, Kaire I, Otter R, Stiller CA, Trama A; RARECAREnet working group. Burden and centralised treatment in Europe of rare tumours: results of RARECAREnet-a population-based study. Lancet Oncol. 2017; 18:1022-1039.

10. Trovik C, Bauer HCF, Styring E, Sundby Hall K, Vult Von Steyern F, Eriksson S, Johansson I, Sampo $M$, Laitinen $M$, Kalén $A$, Jónsson $H$ Jr, Jebsen $N$, Eriksson $M$, Tukiainen $E$, Wall $N$, Zaikova O, Sigurđsson H, Lehtinen T, Bjerkehagen B, Skorpil M, Egil Eide G, Johansson E, Alvegard TA. The Scandinavian Sarcoma Group Central Register: 6,000 patients after 25 years of monitoring of referral and treatment of extremity and trunk wall soft-tissue sarcoma. Acta Orthop. 2017; 88:341-347.

11. Martin-Broto J, Hindi N, Cruz J, Martinez-Trufero J, Valverde C, De Sande LM, Sala A, Bellido L, De Juan A, Rubió-Casadevall J, Diaz-Beveridge R, Cubedo R, Tendero O, Salinas D, Gracia I, Ramos R, Baguè S, Gutierrez A, Duran-Moreno J, Lopez-Pousa A. Relevance of Reference Centers in Sarcoma Care and Quality Item Evaluation: Results from the Prospective Registry of the Spanish Group for Research in Sarcoma (GEIS). Oncologist. 2019; 24:e338-e346.

12. Kollár A, Rothermundt C, Klenke F, Bode B, Baumhoer D, Arndt V, Feller A; NICER Working Group. Incidence, mortality, and survival trends of soft tissue and bone sarcoma in Switzerland between 1996 and 2015. Cancer Epidemiol. 2019; 63:101596.

13. Ressing $M$, Wardelmann E, Hohen berger $P$, Jakob J, Kasper B, Emrich K, Eberle A, Blettner $M$, Zeissig SR. Strengthening health data on a rare and heterogeneous disease: sarcoma incidence and histological subtypes in Germany. BMC Public Health. 2018 Feb 12;18(1):235. doi: 10.1186/s12889-018-5131-4. PubMed PMID: 29433465; PubMed Central PMCID: PMC5809940. Yang Z, Zheng R, Zhang S, Zeng H, Li H, Chen W. Incidence, distribution of histological subtypes and primary sites of soft tissue sarcoma in China. Cancer Biol Med. 2019; 16:565-574.

14. Bessen T, Caughey GE, Shakib S, Potter JA, Reid J, Farshid G, Roder D, Neuhaus SJ. A population-based study of soft tissue sarcoma incidence and survival in Australia: An analysis of 26,970 cases. Cancer Epidemiol. 2019; 63:101590.

15. Gage MM, Nagarajan N, Ruck JM, Canner JK, Khan S, Giuliano K, Gani F, Wolfgang C, Johnston FM, Ahuja N. Sarcomas in the United States: Recent trends and a call for improved staging. Oncotarget. 2019; 10:2462-2474. 
medRxiv preprint doi: https://doi.org/10.1101/2020.06.19.20135467; this version posted June 22, 2020. The copyright holder for this preprint

(which was not certified by peer review) is the author/funder, who has granted medRxiv a license to display the preprint in perpetuity. All rights reserved. No reuse allowed without permission.

16. Lurkin A, Ducimetière F, Vince DR, Decouvelaere AV, Cellier D, Gilly FN, Salameire D, Biron $P$, de Laroche G, Blay JY, Ray-Coquard I. Epidemiological evaluation of concordance between initial diagnosis and central pathology review in a comprehensive and prospective series of sarcoma patients in the Rhone-Alpes region. BMC Cancer. 2010; 10:150.

17. Casali PG, Bielack S, Abecassis N, et al; ESMO Guidelines Committee, PaedCan and ERN EURACAN. Bone sarcomas: ESMO-PaedCan-EURACAN Clinical Practice Guidelines for diagnosis, treatment andfollow-up. Ann Oncol. 2018;29 (Supplement_4):iv79-iv95.

18. Casali PG, Abecassis N, Bauer S, et al. ESMO Guidelines Committee and EURACAN. Gastrointestinal stromal tumours: ESMO-EURACAN Clinical Practice Guidelines for diagnosis, treatment and follow-up. Ann Oncol. 2018;29(Supplement_4):iv68-iv78.

19. Casali PG, Abecassis N, Bauer S, et al; ESMO Guidelines Committee and EURACAN. Soft issue and visceral sarcomas: ESMO-EURACAN Clinical Practice Guidelines for diagnosis, treatment and follow-up. Ann Oncol. 2018;29(Supplement_4):iv51-iv67.

20. von Mehren M, Randall RL, Benjamin RS, et al. Soft Tissue Sarcoma, Version 2.2016, NCCN Clinical Practice Guidelines in Oncology. J Natl Compr Canc Netw. 2016;14:758-86.

21. Dangoor A, Seddon B, Gerrand C, Grimer R, Whelan J, Judson I. UK guidelines for the management of soft tissue sarcomas. Clin Sarcoma Res. 2016;6-20.

22. Perrier $L$, Rascle $P$, Morelle $M$, Toulmonde $M$, Ranchere Vince $D$, Le Cesne $A$, Terrier $P$, Neuville A, Meeus P, Farsi F, Ducimetière F, Blay JY, Ray Coquard I, Coindre JM. The costsaving effect of centralized histological reviews with soft tissue and visceral sarcomas, GIST, and desmoid tumors: The experiences of the pathologists of the French Sarcoma Group. PLoS One. 2018 Apr 5;13(4):e0193330

23. Perrier L, Buja A, Mastrangelo $G$, Vecchiato $A$, Sandonà $P$, Ducimetière $F$, Blay JY, Gilly FN, Siani $C$, Biron $P$, Ranchère-Vince $D$, Decouvelaere AV, Thiesse $P$, Bergeron $C$, Dei Tos AP, Coindre JM, Rossi CR, Ray-Coquard I. Clinicians' adherence versus non adherence to practice guidelines in the management of patients with sarcoma: a cost-effectiveness assessment in two European regions. BMC Health Serv Res. 2012; 12:82.

24. Blay JY, Soibinet P, Penel N, Bompas E, Duffaud F, Stoeckle E, Mir O, Adam J, Chevreau C, Bonvalot $S$, Rios $M$, Kerbrat $P$, Cupissol $D$, Anract $P$, Gouin $F$, Kurtz JE, Lebbe $C$, Isambert $N$, Bertucci $F$, Toumonde $M$, Thyss $A$, Piperno-Neumann $S$, Dubray-Longeras $P$, Meeus $P$, Ducimetière $F$, Giraud A, Coindre JM, Ray-Coquard I, Italiano A, Le Cesne A. Improved survival using specialized multidisciplinary board in sarcoma patients. Ann Oncol. 2017; 28:28522859.

25. Blay JY, Honoré $C$, Stoeckle E, Meeus $P$, Jafari $M$, Gouin F, Anract $P$, Ferron $G$, Rochwerger $A$, Ropars M, Carrere S, Marchal F, Sirveaux F, Di Marco A, Le Nail LR, Guiramand J, Vaz G, Machiavello JC, Marco O, Causeret S, Gimbergues P, Fiorenza F, Chaigneau L, Guillemin F, Guilloit JM, Dujardin F, Spano JP, Ruzic JC, Michot A, Soibinet P, Bompas E, Chevreau C, Duffaud F, Rios M, Perrin C, Firmin N, Bertucci F, Le Pechoux C, Le Loarer F, Collard O, Karanian-Philippe M, Brahmi M, Dufresne A, Dupré A, Ducimetière F, Giraud A, Pérol D, Toulmonde M, Ray-Coquard I, Italiano A, Le Cesne A, Penel N, Bonvalot S; NETSARC/REPPS/RESOS and French Sarcoma Group-Groupe d'Etude des Tumeurs Osseuses (GSF-GETO) Networks. Surgery in reference centers improves survival of sarcoma patients: a nationwide study. Ann Oncol. 2019; 30:1143-1153.

26. Gatta G, van der Zwan JM, Casali PG, Siesling S, Dei Tos AP, Kunkler I, Otter R, Licitra L, Mallone S, Tavilla A, Trama A, Capocaccia R; RARECARE working group. Rare cancers are not so rare: the rare cancer burden in Europe. Eur J Cancer. 2011; 47:2493-511. . 
medRxiv preprint doi: https://doi.org/10.1101/2020.06.19.20135467; this version posted June 22, 2020. The copyright holder for this preprint

(which was not certified by peer review) is the author/funder, who has granted medRxiv a license to display the preprint in perpetuity.

All rights reserved. No reuse allowed without permission.

\section{Legends to the Figures}

\section{Figure 1 : Published clinical trials in sarcoma and TMI histotypes.}

Tabular presentation of different sarcoma histotypes and groups of histotypes by decreasing order together with the documented published clinical trials in Pubmed : if phase III clinical trials are published, the box is highlighted in light green, if randomized phase II trials are published the box is highlighted in dark blue, if uncontrolled phase II trials are published the box is highlighted in light blue.

\section{Supplementary Figure: Variable incidence of sarcoma subtypes between 2013 to 2016}

Presentation of the yearly variation of the eight different histotypes with significantly variable incidence in the period of observation. 
Table 1: incidence of soft tissue and visceral sarcomas

\begin{tabular}{|c|c|c|c|c|c|c|}
\hline & 2013 & 2014 & 2015 & 2016 & Total & $\begin{array}{l}\text { Incidence } \\
/ 10^{6} / \text { year }\end{array}$ \\
\hline Adipocytic tumours & 744 & 821 & 817 & 865 & 3247 & 12,299 \\
\hline Atypical lipomatous tumour / & & & & & & \\
\hline well-differentiated liposarcoma & 289 & 304 & 314 & 357 & 1266 & 4,795 \\
\hline Liposarcoma-dedifferentiated & 304 & 344 & 341 & 356 & 1345 & 5,095 \\
\hline Myxoid Round Cell LPS & 99 & 106 & 108 & 96 & 409 & 1,549 \\
\hline Liposarcoma - myxoid & 81 & 90 & 95 & 89 & 355 & 1,345 \\
\hline Liposarcoma - round cell & 18 & 16 & 13 & 7 & 54 & 0,205 \\
\hline Liposarcoma - pleomorphic & 31 & 41 & 36 & 31 & 139 & 0,527 \\
\hline Lipomatous spindle cell/pleomorphic & 0 & 1 & 0 & 0 & 1 & 0,004 \\
\hline Liposarcoma NOS & 21 & 25 & 17 & 22 & 85 & 0,322 \\
\hline Liposarcoma - mixed type & 0 & 0 & 1 & 1 & 2 & 0,008 \\
\hline Fibroblastic \& myofibroblastic tumours & 1041 & 1047 & 1115 & 1147 & 4349 & 16,473 \\
\hline Desmoid fibromatosis & 307 & 295 & 357 & 381 & 1340 & 5,072 \\
\hline Lipofibromatosis & 3 & 0 & 5 & 0 & 8 & 0,030 \\
\hline Giant cell Fibroblastoma & 2 & 4 & 4 & 1 & 11 & 0,042 \\
\hline Dermatofibrosarcoma Protuberans & 261 & 270 & 258 & 251 & 1040 & 3,939 \\
\hline Solitary fibrous tumour (all) & 210 & 222 & 242 & 252 & 925 & 3,504 \\
\hline Solitary fibrous tumor & 166 & 178 & 193 & 214 & 751 & 2,845 \\
\hline High risk SFT & 44 & 43 & 49 & 38 & 174 & 0,659 \\
\hline Inflammatory myofibroblastic Tum. & 32 & 39 & 33 & 41 & 145 & 0,549 \\
\hline Low grade Myofibroblastic Sarc. & 3 & 5 & 3 & 2 & 13 & 0,049 \\
\hline Myxoinflammatory Fibroblastic Sarc. & 6 & 6 & 6 & 5 & 23 & 0,087 \\
\hline Infantile fibrosarcoma & 3 & 2 & 1 & 4 & 10 & 0,038 \\
\hline Adult fibrosarcoma & 11 & 4 & 9 & 4 & 28 & 0,106 \\
\hline Myxofibrosarcoma & 162 & 160 & 152 & 156 & 630 & 2,386 \\
\hline Low grade fibromyxoid sarcoma & 33 & 30 & 35 & 38 & 136 & 0,515 \\
\hline Sclerosing epithelioid fibrosarcoma & 8 & 11 & 10 & 12 & 41 & 0,155 \\
\hline So-called fibrohistiocytic tumours & 29 & 16 & 37 & 24 & 106 & 0,402 \\
\hline Intermediate fibrohistiocytic tumors & 0 & 0 & 2 & 3 & 5 & 0,019 \\
\hline Malignant tenosynovial giant cell tum. & 1 & 0 & 0 & 1 & 2 & 0,008 \\
\hline Plexiform fibrohistiocytic tumors & 7 & 7 & 9 & 6 & 29 & 0,110 \\
\hline Giant cell tumour of soft tissue & 21 & 9 & 26 & 14 & 70 & 0,265 \\
\hline Vascular tumours & 398 & 377 & 381 & 364 & 1520 & 5,758 \\
\hline Retiform hemangio-endothelioma & 1 & 3 & 3 & 2 & 9 & 0,034 \\
\hline Papillary intralymphatic & & & & & & \\
\hline angioendothelioma & 0 & 0 & 0 & 1 & 1 & 0,004 \\
\hline Composite hemangioendothelioma & 1 & 1 & 1 & 0 & 3 & 0,011 \\
\hline Kaposi sarcoma & 191 & 165 & 162 & 145 & 663 & 2,511 \\
\hline Kaposiform hemangioendothelioma & 1 & 1 & 1 & 1 & 4 & 0,015 \\
\hline Pseudomyogenic hemangioendothelioma & 1 & 3 & 0 & 2 & 6 & 0,023 \\
\hline Epithelioid hemangioEndothelioma & 27 & 20 & 30 & 23 & 100 & 0,379 \\
\hline Angiosarcoma & 176 & 183 & 182 & 187 & 728 & 2,758 \\
\hline Intermediate vascular tumours & 0 & 1 & 2 & 3 & 6 & 0,023 \\
\hline $\begin{array}{l}\text { Pericytic (perivascular) tumours } \\
\text { Malignant glomus tumour }\end{array}$ & 4 & 4 & 1 & 1 & 10 & 0,038 \\
\hline Smooth muscle (SM) tumours & 646 & 698 & 669 & 666 & 2679 & 10,148 \\
\hline SM tumor of undetermined malignancy & 20 & 47 & 23 & 32 & 122 & 0,462 \\
\hline
\end{tabular}


medRxiv preprint doi: https://doi.org/10.1101/2020.06.19.20135467; this version posted June 22, 2020. The copyright holder for this preprint (which was not certified by peer review) is the author/funder, who has granted medRxiv a license to display the preprint in perpetuity. All rights reserved. No reuse allowed without permission.

$\begin{array}{lllllll}\text { Metastatic leiomyoma } & 0 & 0 & 0 & 2 & 2 & 0,008 \\ \text { Leiomyosarcoma } & 247 & 263 & 287 & 297 & 1094 & 4,144 \\ \text { Leiomyosarcoma -differentiated } & 245 & 243 & 240 & 217 & 945 & 3,580 \\ \text { Leiomyosarcoma - poorly differentiated } & 134 & 145 & 119 & 118 & 516 & 1,955 \\ & & & & & & \\ \text { Skeletal muscle sarcoma (RMS) } & 145 & 157 & 173 & 133 & 608 & 2,303 \\ \text { Embryonal RMS } & 50 & 45 & 60 & 34 & 179 & 0,678 \\ \quad \text { Embryonal RMS sarcoma - botryoid type } & 8 & 6 & 6 & 3 & 23 & 0,087 \\ \text { Embryonal rhabdomyosarcoma usual type } & 35 & 31 & 47 & 24 & 137 & 0,519 \\ \quad \text { Embryonal rhabdomyosarcoma spindle cell } & 7 & 8 & 7 & 7 & 29 & 0,110 \\ \text { Alveolar RMS } & 27 & 36 & 35 & 25 & 123 & 0,466 \\ \text { Pleomorphic RMS } & 28 & 38 & 42 & 36 & 144 & 0,545 \\ \text { Sclerosing RMS } & 2 & 3 & 3 & 3 & 11 & 0,042 \\ \text { Spindle cell RMS } & 13 & 8 & 9 & 9 & 39 & 0,148 \\ \text { Adult spindle cell RMS } & 0 & 0 & 1 & 4 & 5 & 0,019 \\ \text { RMS NOS } & 21 & 25 & 23 & 19 & 88 & 0,333 \\ \text { Ectomesenchymoma: Mal. mesenchymoma } & 4 & 2 & 0 & 3 & 9 & 0,034 \\ \text { Gastrointestinal stromal tumors (GIST). } & 736 & 792 & 913 & 831 & 3272 & 12,394 \\ \text { Chondro-osseous tumours } & & & & & & \\ \text { Extraskeletal Osteosarcoma } & & & & & & \\ \text { Peripheral nerve sheath tumours } & 25 & 25 & 32 & 14 & 96 & 0,364 \\ \text { MPNST - epithelioid type } & 75 & 68 & 69 & 74 & 286 & 1,083 \\ \text { MPNST - usual type } & 0 & 2 & 1 & 3 & 6 & 0,023 \\ \text { Malignant peripheral nerve sheath tumour } & 36 & 7 & 14 & 28 & 85 & 0,322 \\ \text { Malignant Triton tumour } & 36 & 55 & 47 & 35 & 173 & 0,655 \\ \text { Malignant granular cell Tumour } & 3 & 2 & 4 & 0 & 9 & 0,034 \\ \text { Malignant perineurioma } & 0 & 0 & 0 & 3 & 3 & 0,011\end{array}$


Table 1 (part 2): incidence of soft tissue and visceral sarcomas

\begin{tabular}{|c|c|c|c|c|c|c|}
\hline & 2013 & 2014 & 2015 & 2016 & Total & $\begin{array}{l}\text { Incidence } \\
\text { /10e6/year }\end{array}$ \\
\hline \multicolumn{7}{|l|}{ Tumours of uncertain differentiation } \\
\hline Atypical fibroxanthoma & 114 & 107 & 89 & 119 & 429 & 1,625 \\
\hline Angiomatoid fibrous histiocytoma & 9 & 15 & 10 & 9 & 43 & 0,163 \\
\hline Ossifying fibromyxoid Tumour & 7 & 7 & 5 & 13 & 32 & 0,121 \\
\hline \multicolumn{7}{|l|}{ Myoepithelioma, myoepithelial carcinoma, } \\
\hline$\&$ mixed tumour & 31 & 26 & 18 & 18 & 96 & 0,364 \\
\hline Myoepithelioma & 30 & 26 & 15 & 14 & 85 & 0,322 \\
\hline Malignant myoepithelial Tumour & 0 & 0 & 1 & 1 & 2 & 0,008 \\
\hline Mixed tumour & 1 & 0 & 2 & 3 & 6 & 0,023 \\
\hline Haemosiderotic fibrolipomatous tumour & 0 & 2 & 0 & 7 & 9 & 0,034 \\
\hline Phosphaturic mesenchymal tumour & 0 & 1 & 2 & 2 & 5 & 0,019 \\
\hline \multicolumn{7}{|c|}{ NTRK-rearranged spindle cell neoplasm (emerging) Not reported in NETSARC (so far) } \\
\hline Synovial sarcoma & 103 & 101 & 133 & 105 & 442 & 1,674 \\
\hline Synovial sarcoma - NOS & 23 & 18 & 29 & 21 & 91 & 0,345 \\
\hline Synovial sarcoma - biphasic & 11 & 19 & 23 & 17 & 70 & 0,265 \\
\hline Synovial sarcoma - monophasic & 60 & 57 & 67 & 60 & 244 & 0,924 \\
\hline Synovial sarcoma - poorly Differentiated & 9 & 7 & 14 & 7 & 37 & 0,140 \\
\hline Epithelioid sarcoma (all) & 29 & 30 & 28 & 33 & 120 & 0,455 \\
\hline Epithelioid sarcoma & 23 & 28 & 25 & 22 & 98 & 0,371 \\
\hline Undifferentiated epithelioid sarcoma & 6 & 2 & 3 & 11 & 22 & 0,083 \\
\hline Alveolar soft part sarcoma & 10 & 7 & 8 & 6 & 31 & 0,117 \\
\hline Clear cell sarcoma of soft tissue & 16 & 26 & 16 & 71 & 0,269 & \\
\hline Extraskeletal myxoid chondrosarcoma & 15 & 12 & 20 & 11 & 58 & 0,220 \\
\hline Desmoplastic small round cell tumour & 14 & 9 & 12 & 17 & 52 & 0,197 \\
\hline Extrarenal rhabdoid tumour & 6 & 13 & 16 & 16 & 51 & 0,193 \\
\hline SMARCA4-deficient thoracic sarcoma & 0 & 0 & 6 & 9 & 15 & 0,057 \\
\hline PEComa, including angiomyolipoma & 13 & 27 & 15 & 29 & 86 & 0,326 \\
\hline PECOMA - NOS & 13 & 25 & 11 & 18 & 67 & 0,254 \\
\hline Malignant PECOMA & 0 & 2 & 4 & 13 & 19 & 0,072 \\
\hline Intimal sarcoma & 14 & 12 & 11 & 9 & 46 & 0,174 \\
\hline Undifferentiated sarcoma (all) & 566 & 627 & 784 & 740 & 2717 & 10,292 \\
\hline Undifferentiated pleomorphic sarcoma & 290 & 367 & 470 & 429 & 1556 & 5,894 \\
\hline Undifferentiated sarcoma & 110 & 87 & 154 & 79 & 430 & 1,629 \\
\hline Undifferentiated sarcoma-NOS & 125 & 130 & 111 & 57 & 423 & 1,602 \\
\hline Undifferentiated spindle cell sarcoma & 41 & 43 & 49 & 175 & 308 & 1,167 \\
\hline Low grade sinonasal sarcoma & 2 & 0 & 0 & 3 & 5 & 0,019 \\
\hline Melanotic neuroectodermal tumour infancy & 0 & 0 & 0 & 1 & 1 & 0,004 \\
\hline Phyllode sarcoma & 32 & 25 & 46 & 35 & 138 & 0,523 \\
\hline \multicolumn{7}{|l|}{ Sarcomas or TIM NOS } \\
\hline - Sarcoma NOS & 166 & 197 & 259 & 189 & 809 & 3,064 \\
\hline - Tumors of intermediate malignancy & 7 & 15 & 13 & 17 & 52 & 0,197 \\
\hline
\end{tabular}


Table 2: Incidence of bone sarcomas in NETSARC+ (2013-2016)

\begin{tabular}{|c|c|c|c|c|c|c|}
\hline & 2013 & 2014 & 2015 & 2016 & Total & $\begin{array}{l}\text { Incidence } \\
/ 10^{6} / \text { year }\end{array}$ \\
\hline \multicolumn{7}{|c|}{$\begin{array}{l}\text { Undifferentiated small round cell sarcomas } \\
\text { (SRCS) of bone and soft tissue }\end{array}$} \\
\hline Ewing sarcoma & 151 & 163 & 153 & 147 & 614 & 2,326 \\
\hline SRCS with EWSR1-non-ETS fusions & 6 & 6 & 8 & 36 & 56 & 0,212 \\
\hline $\mathrm{ClC}$-rearranged sarcoma & 1 & 3 & 3 & 4 & 11 & 0,042 \\
\hline BCOR-rearranged Sarcoma & 2 & 0 & 2 & 3 & 7 & 0,027 \\
\hline \multicolumn{7}{|l|}{$\begin{array}{l}\text { Bone tumours } \\
\text { Chondrogenic tumours }\end{array}$} \\
\hline Chond roblastoma & 11 & 16 & 9 & 16 & 52 & 0,197 \\
\hline $\begin{array}{l}\text { Chondromyxoid fibroma } \\
\text { entral atypical cartilaginous }\end{array}$ & 4 & 7 & 12 & 3 & 26 & 0,098 \\
\hline tumour/chondrosarcoma, gd 1 & 2 & 10 & 19 & 45 & 76 & 0,288 \\
\hline Central chondroS grades 2 and 3 & 22 & 33 & 35 & 27 & 117 & 0,443 \\
\hline Chond rosarcoma NOS & 164 & 125 & 143 & 140 & 572 & 2,167 \\
\hline Peripheral chondrosarcoma & 5 & 6 & 8 & 20 & 39 & 0,148 \\
\hline Periosteal chondrosarcoma & 8 & 4 & 6 & 7 & 25 & 0,095 \\
\hline Clear cell chondrosarcoma & 4 & 3 & 2 & 5 & 14 & 0,053 \\
\hline Mesenchymal chondrosarcoma & 3 & 7 & 11 & 10 & 31 & 0,117 \\
\hline Dedifferentiated chondrosarcoma & 19 & 23 & 20 & 31 & 93 & 0,352 \\
\hline \multicolumn{7}{|l|}{ Osteogenic tumors } \\
\hline Osteoblastoma & 5 & 9 & 8 & 10 & 32 & 0,121 \\
\hline Low grade central osteosarcoma & 4 & 4 & 4 & 7 & 19 & 0,072 \\
\hline Low-grade central osteosarcoma & 2 & 1 & 1 & 3 & 7 & 0,027 \\
\hline Dediff. ow grade central osteosarcoma & 2 & 3 & 3 & 4 & 12 & 0,045 \\
\hline Osteosarcoma & 154 & 169 & 170 & 168 & 661 & 2,504 \\
\hline Osteosarcoma NOS & 39 & 57 & 62 & 72 & 230 & 1,106 \\
\hline Conventional osteosarcoma & 111 & 105 & 105 & 96 & 417 & 1,580 \\
\hline Osteoblastoma-like osteosarcoma & 1 & 0 & 0 & 1 & 2 & 0,008 \\
\hline Telangiectasic osteosarcoma & 2 & 7 & 2 & 5 & 16 & 0,061 \\
\hline Small cell osteosarcoma & 1 & 0 & 1 & 2 & 4 & 0,015 \\
\hline Parosteal osteosarcoma & 7 & 7 & 16 & 10 & 40 & 0,152 \\
\hline - Parosteal osteosarcoma & 6 & 4 & 10 & 7 & 27 & 0,102 \\
\hline - Dedifferentiated parosteal osteoSarc & 1 & 3 & 6 & 3 & 13 & 0,049 \\
\hline Periosteal osteosarcoma & 1 & 4 & 0 & 0 & 5 & 0,019 \\
\hline High-grade surface osteosarcoma & 6 & 5 & 6 & 8 & 25 & 0,095 \\
\hline \multicolumn{7}{|l|}{ Fibrogenic tumors } \\
\hline Desmoplastic fibroma of bone & 0 & 0 & 2 & 4 & 6 & 0,023 \\
\hline Fibrosarcoma of the bone & 0 & 1 & 3 & 0 & 4 & 0,015 \\
\hline \multicolumn{7}{|l|}{ Vascular tumor of bone } \\
\hline Epithelioid haemangioendothelioma & 1 & 2 & 5 & 0 & 8 & 0,030 \\
\hline Angiosarcoma of bone & 7 & 6 & 7 & 9 & 29 & 0,110 \\
\hline \multicolumn{7}{|l|}{ Osteoclastic giant-cell rich } \\
\hline Aneurysmal bone cyst & 14 & 9 & 22 & 8 & 53 & 0,201 \\
\hline Giant cell tumour of bone & 76 & 88 & 87 & 67 & 318 & 1,204 \\
\hline Malignant/dedifferentiated GCTB & 0 & 0 & 2 & 4 & 6 & 0,023 \\
\hline \multicolumn{7}{|l|}{ Notochordal tumours } \\
\hline - Conventional chordoma & 35 & 33 & 42 & 54 & 164 & 0,621 \\
\hline - Dedifferentiated chordoma & 0 & 1 & 1 & 0 & 2 & 0,008 \\
\hline Adamantinoma & 8 & 1 & 2 & 8 & 19 & 0,072 \\
\hline Langerhans cell histiocytosis & 4 & 8 & 4 & 4 & 20 & 0,076 \\
\hline
\end{tabular}


medRxiv preprint doi: https://doi.org/10.1101/2020.06.19.20135467; this version posted June 22,2020 . The copyright holder for this preprint (which was not certified by peer review) is the author/funder, who has granted medRxiv a license to display the preprint in perpetuity.

All rights reserved. No reuse allowed without permission.

Table 3: Incidence of uterine and rare bone sarcomas \& genetic syndromes

\section{Total Incidence \\ /10e6/year}

Uterine sarcoma

Endometrial stromal sarcoma, low grade

Endometrial stromal nodule

Endometrial stromal sarcoma

Endometrial stromal sarcoma-low grade

Endometrial stromal sarcoma - high-grade

Adenosarcoma

Undifferentiated uterine sarcoma

Uterine tumour resembling ovarian sex cord

Uterine leiomyosarcoma

(extracted from the LMS group above)

\section{$\begin{array}{llllll}242 & 311 & 285 & 300 & 1138 & 4,311\end{array}$}

$\begin{array}{llllll}57 & 64 & 55 & 62 & 238 & 0,902 \\ 2 & 1 & 5 & 8 & 16 & 0,061 \\ 0 & 3 & 2 & 5 & 10 & 0,038 \\ 55 & 60 & 48 & 49 & 212 & 0,803 \\ 1 & 5 & 13 & 22 & 41 & 0,155 \\ 28 & 35 & 42 & 51 & 156 & 0,591 \\ 37 & 49 & 38 & 17 & 141 & 0,534 \\ 5 & 1 & 4 & 7 & 17 & 0,064\end{array}$

$\begin{array}{llllll}114 & 157 & 133 & 141 & 545 & 2,064\end{array}$

\section{Rare bone sarcomas}

(extracted from the histological groups in Table 1)

All undifferentiated sarcoma of bone 36

Undifferentiated pleomorphic sarcoma of bone 16

Undifferentiated sarcoma

$36 \quad 31-38$

Undifferentiated spindle cell sarcoma

$\begin{array}{llllll}16 & 11 & 21 & 8 & 56 & 0,212\end{array}$

Undifferentiated epithelioid sarcoma

$\begin{array}{llllll}4 & 0 & 5 & 17 & 26 & 0,098\end{array}$

Leiomyosarcoma of bone

Synovial sarcoma of bone

Rhabdomyosarcoma of bone

BCOR Sarcoma of bone

Myoepithelioma of bone

$\begin{array}{llllll}0 & 0 & 0 & 1 & 1 & 0,004\end{array}$

Liposarcoma of bone

$\begin{array}{llllll}11 & 15 & 5 & 9 & 40 & 0,152 \\ 4 & 2 & 2 & 1 & 9 & 0,034 \\ 2 & 2 & 1 & 4 & 9 & 0,034 \\ 1 & 0 & 2 & 3 & 6 & 0,023 \\ 1 & 1 & 1 & 1 & 4 & 0,015 \\ 0 & 2 & 0 & 2 & 4 & 0,015 \\ 33 & 42 & 46 & 50 & 171 & 0,648\end{array}$

Other histological syubtypes of bone sarcomas 33

\section{Genetic predisposition of soft tissue and bone or HIV}

Enchondromatosis
Li Fraumeni syndrome
Retinoblastoma
Multiple osteochondroma
Neurofibromatosis
Rothmund-Thomson
HIV
Other immunosuppression

$\begin{array}{llllll}5 & 2 & 6 & 4 & 17 & 0,064 \\ 3 & 3 & 4 & 4 & 14 & 0,053 \\ 1 & 0 & 3 & 1 & 5 & 0,019 \\ 2 & 2 & 11 & 5 & 20 & 0,076 \\ 28 & 28 & 24 & 25 & 105 & 0,398 \\ 0 & 1 & 0 & 0 & 1 & 0,004 \\ 4 & 12 & 10 & 6 & 32 & 0,121 \\ 3 & 13 & 4 & 5 & 25 & 0,095\end{array}$


Table 4: Age, gender, sites of histotypes

\begin{tabular}{|c|c|c|c|c|c|c|c|c|c|c|}
\hline \multirow[t]{2}{*}{ Histotypes } & \multirow[b]{2}{*}{$\begin{array}{c}\text { Mean } \\
\text { Age }\end{array}$} & \multirow[b]{2}{*}{$\begin{array}{c}\mathrm{F} / \mathrm{H} \\
\text { Ratio }\end{array}$} & \multirow[b]{2}{*}{ GI } & \multirow[b]{2}{*}{ Gyn } & \multirow[b]{2}{*}{$\mathrm{H} \& \mathrm{~N}$} & \multirow[b]{2}{*}{ I. trnk } & \multicolumn{2}{|c|}{ Sites (\%)* } & \multirow[b]{2}{*}{ U. $\operatorname{limb}$} & \multirow[b]{2}{*}{ Others } \\
\hline & & & & & & & L. limb & Trnk w & & \\
\hline Adamantinoma & 29,1 & 1,71 & 0,0 & 0,0 & 0,0 & 0,0 & 100,0 & 0,0 & 0,0 & 0,0 \\
\hline Adenosarcoma & 61,3 & 51,00 & 1,9 & 89,7 & 0,0 & 3,8 & 0,6 & 0,6 & 0,0 & 3,2 \\
\hline Adult fibrosarcoma & 69,5 & 1,15 & 0,0 & 7,1 & 7,1 & 10,7 & 17,9 & 28,6 & 17,9 & 10,7 \\
\hline Adult spindle cell rhabdomyosarcoma & 52,4 & 0,25 & 0,0 & 0,0 & 20,0 & 0,0 & 20,0 & 40,0 & 20,0 & 0,0 \\
\hline Alveolar rhabdomyosarcoma & 22,7 & 1,05 & 0,0 & 0,8 & 40,7 & 16,3 & 13,8 & 9,8 & 13,8 & 4,9 \\
\hline Alveolar soft part sarcoma & 30,5 & 1,21 & 0,0 & 0,0 & 9,7 & 6,5 & 51,6 & 22,6 & 6,5 & 3,2 \\
\hline Aneurysmal bone cyst & 30,2 & 1,12 & 0,0 & 0,0 & 3,8 & 1,9 & 39,6 & 32,1 & 20,8 & 1,9 \\
\hline Angiomatoid fibrous histiocytoma & 27,1 & 0,87 & 0,0 & 0,0 & 7,0 & 11,6 & 37,2 & 18,6 & 25,6 & 0,0 \\
\hline Angiosarcoma & 67,2 & 1,57 & 1,2 & 0,5 & 14,1 & 7,0 & 9,9 & 21,4 & 3,3 & 42,4 \\
\hline Atypical cartilaginous Tumour/ChondroS G1 & 45 & 1,38 & 0,0 & 0,0 & 3,9 & 0,0 & 36,8 & 14,5 & 43,4 & 1,3 \\
\hline Atypical fibroxanthoma & 78,7 & 0,20 & 0,2 & 0,0 & 12,8 & 0,0 & 1,6 & 82,1 & 1,6 & 1,6 \\
\hline Atypical lipomatous tumor/WDLPS & 64,2 & 0,84 & 0,9 & 0,1 & 2,7 & 29,8 & 44,3 & 14,9 & 5,8 & 1,4 \\
\hline BCOR sarcoma & 18,9 & 0,40 & 0,0 & 0,0 & 0,0 & 28,6 & 28,6 & 42,9 & 0,0 & 0,0 \\
\hline Central chondrosarcoma & 56,4 & 0,98 & 0,0 & 0,0 & 7,7 & 13,7 & 35,0 & 17,1 & 26,5 & 0,0 \\
\hline Chondroblastoma & 24,2 & 0,44 & 0,0 & 0,0 & 5,8 & 0,0 & 63,5 & 17,3 & 13,5 & 0,0 \\
\hline Chondromyxoid fibroma & 34,1 & 0,73 & 0,0 & 0,0 & 3,8 & 0,0 & 42,3 & 30,8 & 23,1 & 0,0 \\
\hline Chondrosarcoma NOS & 54,1 & 0,91 & 0,3 & 0,3 & 13,5 & 20,6 & 25,5 & 21,3 & 17,0 & 1,4 \\
\hline Chordoma & 61,7 & 0,71 & 0,0 & 0,0 & 13,4 & 0,6 & 0,0 & 85,4 & 0,0 & 0,6 \\
\hline CIC-DUX sarcoma & 24,1 & 0,38 & 9,1 & 0,0 & 9,1 & 0,0 & 45,5 & 27,3 & 0,0 & 9,1 \\
\hline Clear cell chondrosarcoma & 42,5 & 0,27 & 0,0 & 0,0 & 0,0 & 7,1 & 64,3 & 7,1 & 21,4 & 0,0 \\
\hline Clear cell sarcoma & 42,3 & 0,87 & 12,7 & 0,0 & 5,6 & 2,8 & 46,5 & 14,1 & 14,1 & 4,2 \\
\hline Composite hemangioendothelioma & 33,3 & 0,50 & 0,0 & 0,0 & 0,0 & 0,0 & 33,3 & 66,7 & 0,0 & 0,0 \\
\hline Conventional osteosarcoma & 32,6 & 0,80 & 0,0 & 0,0 & 12,5 & 3,1 & 60,2 & 14,4 & 9,6 & 0,2 \\
\hline
\end{tabular}




\begin{tabular}{|c|c|c|c|c|c|c|c|c|c|c|}
\hline Dedifferentiated chondrosarcoma & 64 & 0,94 & 0,0 & 0,0 & 1,1 & 11,8 & 48,4 & 30,1 & 7,5 & 1,1 \\
\hline Dedifferentiated chordoma & 53 & NA & 0,0 & 0,0 & 0,0 & 0,0 & 0,0 & 100,0 & 0,0 & 0,0 \\
\hline Dedifferentiated low-grade central osteo & 36,2 & 1,40 & 0,0 & 0,0 & 0,0 & 0,0 & 83,3 & 8,3 & 8,3 & 0,0 \\
\hline Dedifferentiated parosteal osteosarcoma & 43,8 & 2,25 & 0,0 & 0,0 & 7,7 & 0,0 & 76,9 & 7,7 & 7,7 & 0,0 \\
\hline Dermatofibrosarcoma protuberans & 45 & 1,02 & 0,0 & 0,1 & 3,0 & 0,5 & 19,7 & 61,3 & 13,8 & 1,5 \\
\hline Desmoid-type fibromatosis & 43,8 & 2,17 & 15,9 & 0,1 & 3,3 & 7,7 & 7,4 & 59,0 & 6,3 & 0,4 \\
\hline Desmoplastic fibroma of bone & 27,5 & 1,00 & 0,0 & 0,0 & 0,0 & 0,0 & 66,7 & 16,7 & 16,7 & 0,0 \\
\hline $\begin{array}{l}\text { Desmoplastic round cell tumour } \\
\text { Embryonal rhabdomyosarcoma - botryoid }\end{array}$ & 24,3 & 0,30 & 3,8 & 0,0 & 0,0 & 84,6 & 0,0 & 0,0 & 0,0 & 1,5 \\
\hline type & 10,7 & 2,29 & 0,0 & 43,5 & 21,7 & 0,0 & 0,0 & 0,0 & 0,0 & 4,8 \\
\hline Embryonal rhabdomyosarcoma - NOS & 20,3 & 0,71 & 0,0 & 16,7 & 41,7 & 8,3 & 0,0 & 8,3 & 0,0 & 25,0 \\
\hline Embryonal rhabdomyosarcoma - spindle cell & 19 & 0,45 & 0,0 & 6,9 & 31,0 & 37,9 & 0,0 & 6,9 & 3,4 & 3,8 \\
\hline Embryonal rhabdomyosarcoma - usual type & 14,4 & 0,57 & 0,9 & 4,4 & 35,4 & 38,9 & 3,5 & 3,5 & 0,9 & 12,4 \\
\hline Endometrial stromal nodule & 50,7 & NA & 0,0 & 81,3 & 0,0 & 0,0 & 0,0 & 18,8 & 0,0 & 0,0 \\
\hline Endometrial stromal sarcoma NOS & 56,2 & NA & 0,0 & 80,0 & 0,0 & 20,0 & 0,0 & 0,0 & 0,0 & 0,0 \\
\hline Endometrial stromal sarcoma - high-grade & 60 & NA & 0,0 & 95,1 & 0,0 & 4,9 & 0,0 & 0,0 & 0,0 & 0,0 \\
\hline Endometrial stromal sarcoma - low-grade & 53 & 211,00 & 0,5 & 88,7 & 0,0 & 9,4 & 0,0 & 0,5 & 0,0 & 0,9 \\
\hline Epithelioid hemangioendothelioma & 52,1 & 1,56 & 2,0 & 0,0 & 9,0 & 11,0 & 14,0 & 14,0 & 5,0 & 45,0 \\
\hline Epithelioid sarcoma & 40,1 & 0,85 & 1,0 & 6,1 & 2,0 & 12,2 & 22,4 & 19,4 & 29,6 & 7,1 \\
\hline Ewing sarcoma & 26 & 0,68 & 1,0 & 0,5 & 5,7 & 16,6 & 28,2 & 33,6 & 7,8 & 6,7 \\
\hline Extraskeletal myxoid chondrosarcoma & 58,2 & 0,81 & 0,0 & 0,0 & 0,0 & 1,7 & 58,6 & 27,6 & 8,6 & 3,4 \\
\hline Extraskeletal osteosarcoma & 63,1 & 0,78 & 0,0 & 1,0 & 1,0 & 1,0 & 44,8 & 24,0 & 19,8 & 8,3 \\
\hline Fibro-osseous tumour of bone NOS & 36 & NA & 0,0 & 0,0 & 0,0 & 0,0 & 0,0 & 100,0 & 0,0 & 0,0 \\
\hline Fibrosarcomatous dermatofibrosarcoma prot. & 45,6 & 0,65 & 0,0 & 0,0 & 3,4 & 1,7 & 18,8 & 65,0 & 10,3 & 0,9 \\
\hline Gastrointestinal stromal tumour (GIST), & 65,4 & 0,94 & 94,8 & 0,1 & 0,0 & 4,8 & 0,0 & 0,2 & 0,0 & 0,1 \\
\hline Giant cell fibroblastoma & 22 & 0,38 & 0,0 & 0,0 & 0,0 & 0,0 & 54,5 & 45,5 & 0,0 & 0,0 \\
\hline Giant cell tumour of bone & 37,8 & 1,13 & 0,0 & 0,0 & 0,9 & 0,0 & 58,3 & 14,4 & 25,1 & 1,3 \\
\hline Giant cell tumour of soft tissues & 47,5 & 1,41 & 0,0 & 0,0 & 7,1 & 1,4 & 47,1 & 8,6 & 35,7 & 0,0 \\
\hline Hemosiderotic fibrolipomatous tumour & 45,4 & 3,50 & 0,0 & 0,0 & 0,0 & 0,0 & 100,0 & 0,0 & 0,0 & 0,0 \\
\hline High risk solitary fibrous tumour & 64,4 & 0,85 & 2,9 & 0,6 & 8,0 & 31,0 & 6,3 & 13,8 & 1,7 & 6 \\
\hline
\end{tabular}




\begin{tabular}{|c|c|c|c|c|c|c|c|c|c|c|}
\hline High-grade surface osteosarcoma & 44,6 & 0,92 & 0,0 & 0,0 & 24,0 & 12,0 & 44,0 & 20,0 & 0,0 & 0,0 \\
\hline Infantile fibrosarcoma & 5,9 & 2,33 & 10,0 & 0,0 & 20,0 & 10,0 & 20,0 & 20,0 & 0,0 & 20,0 \\
\hline Inflammatory myofibroblastic tumour & 39,3 & 1,10 & 11,0 & 4,1 & 11,7 & 54,5 & 6,2 & 6,9 & 5,5 & 0,0 \\
\hline Intermediate fibrohistiocytic tumours & 41 & 0,25 & 0,0 & 0,0 & 0,0 & 0,0 & 60,0 & 0,0 & 40,0 & \\
\hline Intermediate vascular tumours & 64,7 & 5,00 & 0,0 & 0,0 & 16,7 & 0,0 & 0,0 & 83,3 & 0,0 & \\
\hline Intimal sarcoma & 58,9 & 0,92 & 0,0 & 0,0 & 0,0 & 39,1 & 2,2 & 0,0 & 0,0 & I , \\
\hline Kaposi sarcoma & 65,8 & 0,22 & 1,1 & 0,0 & 3,2 & 1,1 & 65,8 & 11,5 & 13,4 & \\
\hline Kaposiform hemangioendothelioma & 6 & 3,00 & 0,0 & 0,0 & 0,0 & 0,0 & 50,0 & 50,0 & 0,0 & \\
\hline Langerhans cell histiocytosis & 29,5 & 4,00 & 0,0 & 0,0 & 10,0 & 5,0 & 5,0 & 75,0 & 5,0 & \\
\hline Leiomyosarcoma & 63,5 & 2,18 & 4,8 & 35,3 & 7,1 & 18,7 & 15,1 & 8,0 & 4,9 & \\
\hline Leiomyosarcoma - differentiated & 63,1 & 1,23 & 4,9 & 18,2 & 6,1 & 24,2 & 18,4 & 11,5 & 9,7 & \\
\hline Leiomyosarcoma - poorly-differentiated & 70,3 & 0,73 & 3,7 & 8,9 & 29,7 & 9,7 & 19,4 & 15,3 & 7,6 & \\
\hline Lipofibromatosis & 10,3 & 1,00 & 12,5 & 0,0 & 12,5 & 0,0 & 12,5 & 50,0 & 12,5 & 0,0 \\
\hline Lipomatous spindle cell/pleomorphic tum & 33 & NA & 0,0 & 0,0 & 0,0 & 0,0 & 100,0 & 0,0 & 0,0 & \\
\hline Liposarcoma - dedifferentiated & 67,9 & 0,60 & 2,0 & 0,3 & 1,6 & 69,5 & 11,4 & 9,5 & 2,2 & \\
\hline Liposarcoma - mixed type & 61 & 1,00 & 0,0 & 0,0 & 0,0 & 50,0 & 50,0 & 0,0 & 0,0 & \\
\hline Liposarcoma - myxoid & 47,8 & 0,81 & 0,3 & 0,3 & 0,0 & 4,8 & 77,5 & 14,4 & 2,3 & 0 \\
\hline Liposarcoma - NOS & 64,2 & 0,57 & 1,2 & 1,2 & 2,4 & 38,8 & 31,8 & 11,8 & 8,2 & \\
\hline Liposarcoma - pleomorphic & 63,1 & 0,78 & 0,7 & 0,7 & 3,6 & 15,1 & 38,1 & 22,3 & 15,8 & 3,6 \\
\hline Liposarcoma - round cell & 49,2 & 0,59 & 0,0 & 0,0 & 0,0 & 14,8 & 63,0 & 14,8 & 7,4 & \\
\hline Low grade fibromyxoid sarcoma & 42,5 & 0,97 & 0,0 & 0,0 & 9,6 & 5,9 & 34,6 & 36,8 & 11,0 & 2 \\
\hline Low grade myofibroblastic sarcoma & 40,5 & 1,17 & 7,7 & 0,0 & 46,2 & 0,0 & 23,1 & 23,1 & 0,0 & \\
\hline Low grade sinonasal sarcoma & 37,6 & 1,50 & 0,0 & 20,0 & 80,0 & 0,0 & 0,0 & 0,0 & 0,0 & \\
\hline Low-grade central osteosarcoma & 33,6 & 2,50 & 0,0 & 0,0 & 0,0 & 14,3 & 71,4 & 0,0 & 14,3 & 0 \\
\hline Malignant glomus tumour & 54,2 & 0,67 & 20,0 & 10,0 & 10,0 & 10,0 & 30,0 & 0,0 & 20,0 & \\
\hline Malignant granular cell tumour & 46,1 & 1,25 & 0,0 & 0,0 & 0,0 & 0,0 & 0,0 & 55,6 & 44,4 & \\
\hline Malignant mesenchymoma & 61,1 & 1,25 & 0,0 & 11,1 & 0,0 & 11,1 & 33,3 & 0,0 & 33,3 & 1,1 \\
\hline Malignant mixed tumor & 67,5 & NA & 25,0 & 75,0 & 0,0 & 0,0 & 0,0 & 0,0 & 0,0 & \\
\hline Malignant myoepithelial tumour & 49,5 & 1,00 & 0,0 & 0,0 & 0,0 & 0,0 & 0,0 & 50,0 & 50,0 & \\
\hline Malignant PECOMA & 60,1 & 1,71 & 15,8 & 21,1 & 0,0 & 26,3 & 10,5 & 10,5 & 0,0 & \\
\hline
\end{tabular}




\begin{tabular}{|c|c|c|c|c|c|c|c|c|c|c|}
\hline Malignant perineurioma & 46,3 & 2,00 & 0,0 & 0,0 & 0,0 & 0,0 & 33,3 & 33,3 & 0,0 & 33,3 \\
\hline Malignant peripheral nerve sheath tumour & 46,4 & 0,86 & 0,6 & 0,0 & 11,6 & 17,3 & 24,9 & 31,2 & 9,8 & 4,6 \\
\hline Malignant rhabdoid tumour & 24,3 & 0,89 & 2,8 & 8,3 & 13,9 & 16,7 & 5,6 & 16,7 & 0,0 & 36,1 \\
\hline Malignant tenosynovial giant cell tumour & 68,5 & 0,00 & 0,0 & 0,0 & 0,0 & 50,0 & 0,0 & 50,0 & 0,0 & 0,0 \\
\hline Malignant Triton tumour & 34,7 & 1,00 & 0,0 & 0,0 & 30,0 & 40,0 & 0,0 & 30,0 & 0,0 & 0,0 \\
\hline $\begin{array}{l}\text { Malignant/dedifferentiated giant cell tumor of } \\
\text { the bone }\end{array}$ & 40 & 1,00 & 0,0 & 0,0 & 0,0 & 0,0 & 80,0 & 0,0 & 20,0 & 0,0 \\
\hline Melanotic neuroectodermal tumour of infa & 38 & NA & 0,0 & 0,0 & 0,0 & 100,0 & 0,0 & 0,0 & 0,0 & 0,0 \\
\hline Mesenchymal chondrosarcoma & 34,9 & 0,72 & 0,0 & 0,0 & 29,0 & 12,9 & 29,0 & 25,8 & 0,0 & 3,2 \\
\hline Metastatic leiomyoma & 39 & NA & 0,0 & 0,0 & 0,0 & 50,0 & 0,0 & 50,0 & 0,0 & 0,0 \\
\hline Mixed tumour & 66 & NA & 0,0 & 0,0 & 0,0 & 50,0 & 50,0 & 0,0 & 0,0 & 0,0 \\
\hline MPNST - epithelioid type & 43,2 & 2,00 & 0,0 & 0,0 & 0,0 & 16,7 & 16,7 & 50,0 & 16,7 & 0,0 \\
\hline MPNST - usual type & 45,4 & 0,77 & 1,2 & 1,2 & 14,1 & 12,9 & 27,1 & 27,1 & 11,8 & 4,7 \\
\hline Myoepithelioma & 50,6 & 0,89 & 0,0 & 0,0 & 3,5 & 3,5 & 37,6 & 27,1 & 25,9 & 2,4 \\
\hline Myxofibrosarcoma & 68,9 & 0,70 & 0,2 & 0,0 & 2,7 & 2,1 & 46,0 & 18,6 & 28,4 & 2,1 \\
\hline Myxoinflammatory fibroblastic sarcoma & 54,3 & 0,53 & 0,0 & 0,0 & 0,0 & 0,0 & 39,1 & 0,0 & 60,9 & 0,0 \\
\hline Osseous tumour rich in giant cell NOS & 40,5 & 1,00 & 0,0 & 0,0 & 0,0 & 0,0 & 50,0 & 50,0 & 0,0 & 0,0 \\
\hline Ossifying fibromyxoid tumour & 49,8 & 1,13 & 0,0 & 0,0 & 9,4 & 6,3 & 12,5 & 37,5 & 34,4 & 0,0 \\
\hline Osteoblastoma & 26,5 & 0,48 & 0,0 & 0,0 & 3,2 & 0,0 & 19,4 & 58,1 & 19,4 & 0,0 \\
\hline Osteoblastoma-like osteosarcoma & 29 & NA & 0,0 & 0,0 & 0,0 & 0,0 & 100,0 & 0,0 & 0,0 & 0,0 \\
\hline Osteogenic tumor of uncertain prognosis & 22 & NA & 0,0 & 0,0 & 0,0 & 0,0 & 0,0 & 100,0 & 0,0 & 0,0 \\
\hline Osteosarcoma NOS & 38,3 & 0,64 & 0,0 & 0,0 & 15,7 & 2,6 & 51,3 & 19,1 & 9,1 & 2,2 \\
\hline Papillary intralymphatic angioendothelio & 13 & NA & 0,0 & 0,0 & 0,0 & 0,0 & 0,0 & 100,0 & 0,0 & 0,0 \\
\hline Parosteal osteosarcoma & 33,6 & 2,86 & 0,0 & 0,0 & 0,0 & 3,7 & 85,2 & 0,0 & 11,1 & 0,0 \\
\hline PECOMA - NOS & 55,7 & 3,79 & 11,9 & 25,4 & 3,0 & 41,8 & 6,0 & 4,5 & 1,5 & 6,0 \\
\hline Periosteal chondrosarcoma & 41,3 & 1,08 & 4,0 & 0,0 & 0,0 & 8,0 & 32,0 & 24,0 & 32,0 & 0,0 \\
\hline Periosteal osteosarcoma & 19,8 & 4,00 & 0,0 & 0,0 & 0,0 & 20,0 & 80,0 & 0,0 & 0,0 & 0,0 \\
\hline Peripheral chondrosarcoma & 37,3 & 0,63 & 0,0 & 0,0 & 0,0 & 10,3 & 33,3 & 33,3 & 23,1 & 0,0 \\
\hline Phosphaturic mesenchymal tumour & 55,8 & 0,67 & 0,0 & 0,0 & 0,0 & 0,0 & 40,0 & 60,0 & 0,0 & 0,0 \\
\hline Phyllodes sarcoma & 51,3 & 137,00 & 0,0 & 0,0 & 0,0 & 1,4 & 0,0 & 13,0 & 0,0 & 85,5 \\
\hline
\end{tabular}




\begin{tabular}{|c|c|c|c|c|c|c|c|c|c|c|}
\hline Pleomorphic rhabdomyosarcoma & 67 & 0,58 & 1,4 & 7,6 & 5,6 & 11,8 & 36,1 & 19,4 & 11,1 & 6,9 \\
\hline Plexiform fibrohistiocytic tumour & 23,1 & 1,23 & 0,0 & 0,0 & 6,9 & 3,4 & 34,5 & 24,1 & 31,0 & 0,0 \\
\hline Pseudomyogenic hemangioend othelioma & 37,3 & 1,00 & 0,0 & 0,0 & 0,0 & 0,0 & 50,0 & 50,0 & 0,0 & 0,0 \\
\hline Retiform hemangioendothelioma & 40,2 & 0,80 & 0,0 & 0,0 & 0,0 & 0,0 & 22,2 & 44,4 & 33,3 & 0,0 \\
\hline Rhabdomyosarcoma - NOS & 41,7 & 0,80 & 1,1 & 13,6 & 17,0 & 23,9 & 11,4 & 4,5 & 5,7 & 22,7 \\
\hline Sclerosing epithelioid fibrosarcoma & 55,8 & 1,05 & 0,0 & 0,0 & 9,8 & 17,1 & 14,6 & 41,5 & 9,8 & 7,3 \\
\hline Sclerosing rhabdomyosarcoma & 45,2 & 0,38 & 0,0 & 0,0 & 9,1 & 0,0 & 72,7 & 0,0 & 9,1 & 9,1 \\
\hline Small cell osteosarcoma & 21,8 & 0,33 & 0,0 & 0,0 & 0,0 & 25,0 & 25,0 & 0,0 & 25,0 & 25,0 \\
\hline SMARCA4-deficient thoracic sarcoma & 48,3 & 0,25 & 13,3 & 0,0 & 0,0 & 40,0 & 0,0 & 0,0 & 0,0 & 46,7 \\
\hline Smooth muscle tumour of undetermined mal & 50,6 & 4,30 & 6,6 & 59,8 & 0,8 & 15,6 & 5,7 & 7,4 & 4,1 & 0,0 \\
\hline Solitary fibrous tumour & 58 & 1,25 & 1,2 & 1,1 & 15,4 & 21,0 & 13,3 & 18,6 & 4,3 & 25,0 \\
\hline Spindle cell rhabdomyosarcoma & 38,8 & 0,63 & 5,1 & 2,6 & 17,9 & 20,5 & 28,2 & 10,3 & 12,8 & 2,6 \\
\hline Suspicion of giant cell tumour of bone & 56,3 & 0,00 & 0,0 & 0,0 & 0,0 & 0,0 & 33,3 & 0,0 & 66,7 & 0,0 \\
\hline Sarcoma NOS & 59,2 & 1,03 & 4,7 & 7,7 & 11,0 & 13,3 & 21,8 & 18,0 & 11,4 & 12,1 \\
\hline Synovial sarcoma - biphasic & 41,2 & 0,84 & 1,4 & 0,0 & 5,7 & 5,7 & 52,9 & 17,1 & 10,0 & 7,1 \\
\hline Synovial sarcoma - monophasic & 42,8 & 1,18 & 1,2 & 0,0 & 4,9 & 9,4 & 42,6 & 13,1 & 15,6 & 13,1 \\
\hline Synovial sarcoma NOS & 45,6 & 1,22 & 0,0 & 1,1 & 5,5 & 8,8 & 34,1 & 13,2 & 16,5 & 20,9 \\
\hline Synovial sarcoma - poorly differentiated & 45,2 & 0,85 & 0,0 & 0,0 & 5,4 & 10,8 & 29,7 & 18,9 & 8,1 & 27,0 \\
\hline Telangiectasic osteosarcoma & 25,1 & 0,60 & 0,0 & 0,0 & 6,3 & 0,0 & 75,0 & 0,0 & 18,8 & 0,0 \\
\hline Tumour of intermediate malignancy NOS & 47 & 1,14 & 5,8 & 3,8 & 13,5 & 13,5 & 21,2 & 19,2 & 21,2 & 1,9 \\
\hline Undifferentiated epithelioid sarcoma & 70 & 0,47 & 0,0 & 0,0 & 13,6 & 18,2 & 22,7 & 13,6 & 27,3 & 4,5 \\
\hline Undifferentiated pleomorphic sarcoma & 69,2 & 0,79 & 1,7 & 0,8 & 15,6 & 7,6 & 35,0 & 19,6 & 14,0 & 5,7 \\
\hline Undifferentiated round cell sarcoma & 41,2 & 1,33 & 1,8 & 5,4 & 10,7 & 16,1 & 23,2 & 23,2 & 3,6 & 16,1 \\
\hline Undifferentiated sarcoma & 66,7 & 0,89 & 1,4 & 3,3 & 15,8 & 13,0 & 29,5 & 21,4 & 8,8 & 6,7 \\
\hline Undifferentiated sarcoma - NOS & 62,5 & 0,86 & 1,2 & 4,5 & 23,2 & 14,4 & 18,9 & 18,2 & 6,1 & 13,5 \\
\hline Undifferentiated spindle cell sarcoma & 64,1 & 0,79 & 1,6 & 2,3 & 19,8 & 11,7 & 23,7 & 19,8 & 9,7 & 11,4 \\
\hline Undifferentiated uterine sarcoma & 63,8 & NA & 0,0 & 96,1 & 0,0 & 2,9 & 0,0 & 1,0 & 0,0 & 0,0 \\
\hline Uterine tumour resembling ovarian sex co & 48,1 & NA & 5,9 & 94,1 & 0,0 & 0,0 & 0,0 & 0,0 & 0,0 & 0,0 \\
\hline
\end{tabular}


${ }^{*}$ : Sites : Gl : gastrointestinal ; Gyn : Gynaecological sites; H\&N : head and neck ; I. trnk : Internal trunk; L. Limb : lower limb ; Trnk w : trunk wall ; U. limb : upper $\operatorname{limb}$ 


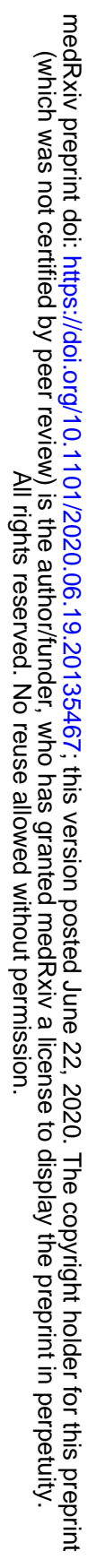




\section{blished clinical trials and TMI histotypes}

\begin{tabular}{|c|c|c|c|c|c|}
\hline types & Total & Incidence & Ph III & RPh II & Ph II \\
\hline & (2013-2016) & $/ 10^{6} /$ year & & & \\
\hline & 25172 & 95,104 & & & \\
\hline & & & & & \\
\hline Imours & 5274 & 19,977 & & & \\
\hline \multirow[t]{4}{*}{ GIST). } & 3272 & 12,394 & & & \\
\hline & 3247 & 12,299 & & & \\
\hline & 2717 & 10,292 & & & \\
\hline & 2679 & 10,148 & & & \\
\hline & & & & & \\
\hline & & & & & \\
\hline \multirow[t]{4}{*}{ soma } & 1556 & 5,894 & & & \\
\hline & 1520 & 5,758 & & & \\
\hline & 1345 & 5,095 & & & \\
\hline & 1339 & 5,072 & & & \\
\hline \multirow[t]{3}{*}{ 's } & 1266 & 4,795 & & & \\
\hline & 1138 & 4,311 & & & \\
\hline & 1094 & 4,144 & & & \\
\hline \multirow[t]{14}{*}{; } & 1040 & 3,939 & & & \\
\hline & 945 & 3,580 & & & \\
\hline & 925 & 3,504 & & & \\
\hline & 853 & 3,231 & & & \\
\hline & 809 & 3,064 & & & \\
\hline & 751 & 2,845 & & & \\
\hline & 728 & 2,758 & & & \\
\hline & 663 & 2,511 & & & \\
\hline & 661 & 2,504 & & & \\
\hline & 630 & 2,386 & & & \\
\hline & 614 & 2,326 & & & \\
\hline & 608 & 2,303 & & & \\
\hline & 572 & 2,167 & & & \\
\hline & 545 & 2,064 & & & \\
\hline \multirow[t]{8}{*}{ tiated } & 516 & 1,955 & & & \\
\hline & 442 & 1,674 & & & \\
\hline & 429 & 1,625 & & & \\
\hline & 409 & 1,549 & & & \\
\hline & 417 & 1,580 & & & \\
\hline & 355 & 1,345 & & & \\
\hline & 330 & 1,250 & & & \\
\hline & 324 & 1,227 & & & \\
\hline sma & 308 & 1,167 & & & \\
\hline urs & 286 & 1,083 & & & \\
\hline
\end{tabular}

\section{Incidence $<1 / 10^{6} /$ year}

synovial sarcoma - monoph asic

Endome trial stromal sarcoma, low grad

teosarcoma NOS

entring

Wheral nerve sheath tumor

her histological subtypes of bone sarcomas

Conventional chordoma
Adenosarcoma

All undifferentiated sarcoma of bone

inflammatory myofibrobl astic Tumour

Ple omorphic RMS

Undifferentiated uterine sarcoma

Liposarcoma - pleomorphic

Phyllode sarcoma

作

Avedar RMS

pithelioid sarcoma (all)

a, grades 2 and 3

brohistiocytic tumours

Spithelioid he mangioEnd othellon

Extraskeletal osteosarcoma

Myoepithelioma, myoepithelial carcinoma, and mixed tumo

Dedifferentiated chondrosarcoma

Shabdomyosarcoma NOS

Liposarcoma NOS

MPNST - usual type

oepithelioma

cartilaginous tumour / chondrosarcoma, grade 1

Cle ar cell sarcoma of soft tissue

Synovial sarcoma - biphasic

Undifferentiated pleomorphic sarcoma of bone

PECOMA-NOS

Extraskeletal myxoid chondrosarcoma

Round cell sarcoma with EWSR1-non-ETS fusions

Aneurysmal bone cyst

Desmoplastic small round cell tumour

All tumors of intermediate malignancy NOS

chondroblastoma

timal sarcoma

Angiomatoid fibrous histiocytoma

clerosing epithelioid fibrosarcoma

Endome trial stromal sarcoma - high-grade

All parosteal osteosarcoma

Leiomyosarcoma of
Spindle cell RMS

eripheral chondrosarcoma

Snovial sarcoma - poorly Differentiated

Malignant rhabdoid tumor

ving fibromyxoid Tumo

Mesenchymal chondros arcoma

Osteoblastoma

Plexiform fibrohistiocytic tumors

Embryonal rhabdomyosarcoma spindle cell

Anglosacoma orbone

Parosteal oste osarcom

\section{Total Incidence Ph III RPh II Ph II (2013-2016) $/ 10^{6} /$ year}

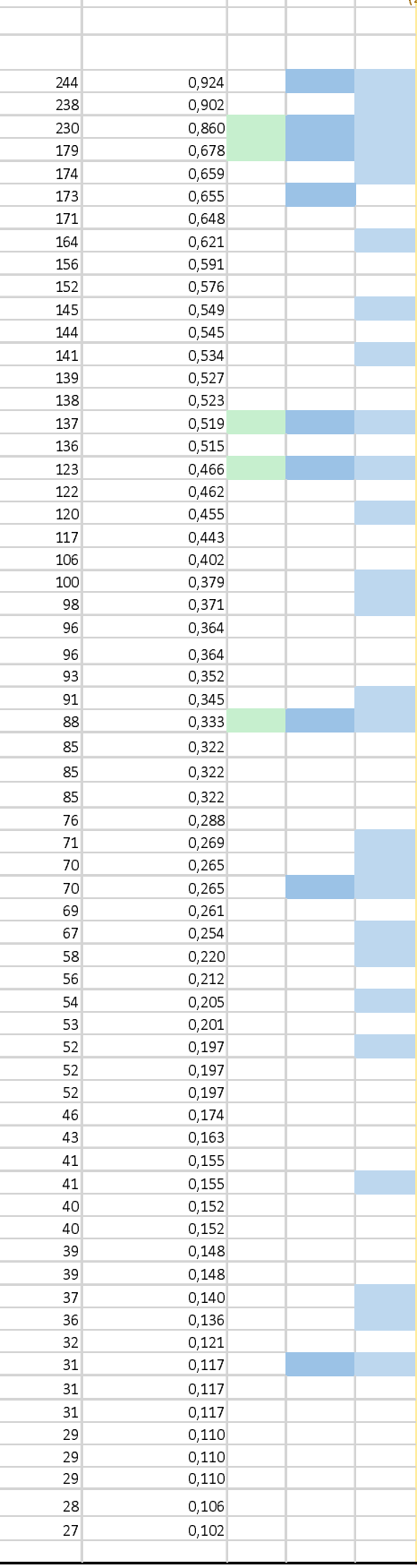

Histotypes

Incidence $<0.1 / 10^{6} /$ year

Chondromyxoid fibroma

ated spindle cell sarcoma

riosteal chondrosarcoma

High-grade surface osteosarcoma

mbon

Mndiferid type

Langerhans cell histiocytosis

Low grade central osteosarcoma (ALL)

Adamanti

Endometrial stromal nodule

Telangiectasic osteos ar coma

Clearcell dondrosicoma

Low grade Myofibroblastic sa

Dedifferentiated parsteal osteosarcoma

Dedifferentiated low grade central osteosarcen

Giant cell Fibroblastoma

Sderosing RMS

CIC-rearranged sarcoma

Infantile fibrosarcoma

Malignant Triton tumour

Endometrial stromal sarcom

Retiform hemangio-endothelio

Malignant granular cell Tumour

Haemosiderotic fibrolipomat

RMS of bone

pithelioid hemangioendothelioma of bone

Sarcoma with BCOR genetic alteration

rade central osteosarcoma

vogenic hemangioendotheliom

Intermediate vascular tumours

MPNST - epithelioid typ

Desmoplastic fibroma of bone

BCorsarcoma fibone

Low grade sinonasal sarcoma

Periosteal osteosarcoma

Kaposiform hemangioendotheliom

Small cell osteosarcoma

Myoepithelioma of bon

ciposactoma thone

(a)

Adult fibrosarcoma of bone

Liposarcoma - mixed type

Malignant tenosynovial giant cell tumors

Metastatic leiomyoma

Malignant myoepithelial Tumour

Dedifferentiated chordoma

Lipomatous spindle cell/pl

Melanotic neuroectodermal tumour of infano

Osteogenic tumor of uncertain prognosis

Fibro-osse ous tumour of bone NOS
Malignant/dedifferentiated GCTB

Papillary intralymphatic angioendetheliom

\begin{tabular}{l|l}
\hline Total & Inc \\
\hline$(2013-2016)$ & $/ 1 C$ \\
\hline
\end{tabular}

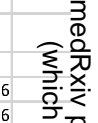

